\title{
MODEL INTERAKSI PELAKU HUTAN RAKYAT DALAM PERDAGANGAN KAYU: PENDEKATAN SIMULASI MODEL BERBASIS AGEN
}

\author{
(The Interaction Model of Community Forest Behavior in Wood Trade: Agent Based \\ Modelling Approach)
}

\author{
Lutfy Abdulah \\ Pusat Penelitian dan Pengembangan Hutan \\ Jl. Gunung Batu No. 5 Po Box 165 Bogor, Jawa Barat, Indonesia \\ Telp. 0251-8633234; Fax 0251-8638111 \\ E-mail: lutfyabdulah@yahoo.co.id
}

Tanggal diterima: 27 Mei 2017; Tanggal direvisi: 22 Mei 2019; Tanggal disetujui; 31 Mei 2019

\begin{abstract}
The sustainability of private forest depended on market mechanisms and the role of policy act. It is a result of interaction among agents. The aim of this study is to find the best strategy in strengthening the position of wood products in trade and its implication for existence of private forest using agent based modeling. The modeling is made using open sources software i.e. Netlogo. The result showed that if there is no competitor's market share, then forest cover tends to be stable. Conversely, if there are competitors, then the community will tend to convert their forest land to other land uses. In this situation, government must take a position by issuing wood trade policies. There are two strategies might be taken, i.e. setting based price for wood products or facilitating trade cartel. First strategy will provide impact like reducing deforestation but only temporary. While, the second strategy will induce the productivity of private forest farmers and maintain forest sustainability by delaying forest conversion and improving land cover with forest. This model needs to be developed by adding variables production capacity and others.
\end{abstract}

Key words: agent based modeling, private forest, construction wood, wood trade

\begin{abstract}
ABSTRAK
Kelestarian hutan rakyat sangat bergantung pada mekanisme pasar dan peran kebijakan pembangunan kehutanan yang merupakan interaksi perilaku pemangku kepentingan dalam rantai pemasaran. Penelitian ini bertujuan untuk mencari strategi terbaik dalam memperkuat posisi kayu dalam perdagangan kayu konstruksi dan implikasinya kepada keberadaan hutan rakyat dengan menggunakan pendekatan pemodelan berbasis aktor (agent based modelling). Pemodelan menggunakan perangkat lunak yang digratiskan seperti Netlogo. Hasil penelitian menunjukkan bahwa jika pangsa pasar kayu tidak ada pesaing, maka tutupan hutan cenderung stabil. Sebaliknya jika ada pesaing, maka masyarakat akan cenderung mengonversi lahan hutannya untuk peruntukan lahan lainnya. Pada kondisi ini, pemerintah harus mengambil posisi dalam bentuk mengeluarkan kebijakan perdagangan kayu. Ada dua strategi yang ditawarkan yakni: penetapan harga dasar kayu dan fasilitasi kartel perdagangan kayu. Hasil simulasi menunjukkan bahwa harga dasar kayu yang bersifat statis akan menjadi jawaban untuk menahan konversi hutan, namun tidak untuk jangka panjang. Sementara strategi kartel perdagangan dengan kelembagaan yang solid akan membantu meningkatkan produktivitas petani hutan rakyat dan mempertahankan kelestarian hutan dengan menghambat konversi hutan dan meningkatkan tutupan lahan oleh hutan. Model yang sudah tersedia perlu dikembangkan dengan menambahkan variabel kapasitas produksi dan lain-lain.
\end{abstract}

Kata kunci: Hutan rakyat, kayu konstruksi, pemodelan berbasis aktor, perdagangan kayu

\section{PENDAHULUAN}

Pembangunan hutan rakyat merupakan upaya untuk mendorong pemenuhan bahan baku kayu dan juga untuk tujuan meningkatkan simpanan karbon. Istilah hutan rakyat menggiring pada status pemilikan sumberdaya. Status tersebut adalah milik pribadi. Hal ini berarti bahwa keputusan dalam pemilihan jenis pohon, jarak tanam, teknik silvikultur, dan waktu 
panen bergantung pada pemilik hutan rakyat itu sendiri.

Perilaku pemilik hutan rakyat dinamis. Perubahan perilaku cenderung dipengaruhi oleh situasi pasar, dalam hal ini terkait nilai uang yang diterima ketika ditebang. Sementara diketahui bersama bahwa pendapatan sangat dipengaruhi oleh harga. Harga kayu dibentuk di pasar yang bersaing bebas dengan pesaingnya. Salah satu pesaing terkuat kayu terutama dalam bidang konstruksi adalah baja ringan. Pada umumnya masyarakat menganggap bahwa baja ringan dianggap lebih murah, mudah diperoleh, serta memiliki kualitas yang lebih baik. Namun beberapa penelitian menyebutkan bahwa penggunaan bahan pengganti kayu justru berpotensi menimbulkan kerusakan lingkungan (Taylor \& Langenberg, 2003). Kayo \& Noda (2018) menyatakan bahwa penggunaan kayu dapat menurunkan emisi tahunan sebesar $17 \%$, namun jika menggunakan bahan pengganti, maka akan meningkatkan emisi dari konstruksi sebesar $88 \%$ dan dari furnitur sebesar $8 \%$.

Beberapa strategi yang dapat ditempuh antara lain melalui promosi penggunaan kayu. Hal ini karena konsumsi kayu berkaitan erat dengan jumlah pengguna dan kemampuan untuk membeli kayu (Tian, Li, Wan, Liu, \& de Jong, 2017). Dengan promosi penggunaan kayu, maka akan meningkatkan pendapatan nasional (Kayo, Tsunetsugu, \& Tonosaki, 2015). Strategi lain adalah dengan menetapkan harga dasar dan pembentukan kartel perdagangan yang dipercaya akan mampu memperbaiki nilai tawar kayu rakyat (Nurrochmat, Darusman, \& Ekayani, 2016). Selain itu perlu dilakukan kerjasama antara pengusaha baja ringan dengan kayu rakyat dalam bentuk pembagian keuntungan (benefit share) sehingga masing-masing pihak samasama mendapatkan manfaat sehingga kelestarian pembangunan hutan dapat terwujud (Roma \& Perrone, 2016).

Kelestarian dalam kehutanan didefinisikan sebagai kelestarian produksi kayu, meski terdapat pendekatan yang sifatnya multi dimensi meliputi pendekatan sosial, ekologi, dan ekonomi yang perlu dipertimbangkan secara bersama-sama dalam suatu unit manajemen (Karvonen, Halder, Kangas, \& Leskinen, 2017). Kelestarian hutan merupakan interaksi antara sumberdaya dan aktor serta kegiatan yang memengaruhi interaksi keduanya. Kelestarian hutan rakyat dapat terjadi karena interaksi antara komponen industri-pemasaran-penyedia kayu dan interaksi antar komponen tersebut dengan lingkungan yang lebih luas sehingga keberadaan hutan rakyat itu stabil. Konsep ini kemudian disebut lestari (Nurrochmat et al., 2016).

Penelitian tentang persepsi dan sikap pemangku kepentingan dalam menjaga kelestarian alam terus berkembang. Pendekatan permodelan merupakan metode yang mudah dan murah sehingga mampu memproyeksikan kondisi sumberdaya alam baik secara dinamis maupun statis. Saat ini, praktek pemodelan mengarah kepada dua hal penting yakni alasan di balik pilihan-pilihan pembuatan keputusan dari suatu model yang sering tidak terdokumentasi dengan baik yang disebabkan oleh data empiris, dan teoritis yang ada yang tidak cukup kuat menjelaskan pilihan tersebut sehingga model hanya berupa asumsi. Untuk memetakan perilaku terutama pelaku konsumen pemula, maka diperlukan sistem informasi yang cukup (Osburg, Appelhanz, Toporowski, \& Schumann, 2016).

Dalam hal mempelajari interaksi tersebut dengan berbagai kepentingan para pemangku kepentingan, maka perlu pendekatan pemodelan dalam memproyeksikan dampak interaksi terhadap sumberdaya. Hal ini rumit, namun penting dan tidak sesederhana dengan menggunakan pendekatan linier. Sebagai contoh pendekatan linier programming untuk menentukan nilai ekonomi lahan hutan 
tanaman rakyat yang ditanam dengan berbagai variasi jenis tanaman dan kemudian menyimpulkan adanya pengaruh harga pasar terhadap nilai lahan (Hefni, Lahjie, Sardjono, Ruchaemi, \& Agang, 2012).

Untuk itu, penelitian ini dilakukan dalam rangka membangun sebuah model simulasi berbasis agen dalam pemasaran dan penggunaan produk kayu yang mempengaruhi keberadaan hutan, pendapatan dari hasil produksi kayu, dan pengaruh keberadaan baja ringan terhadap hutan. Oleh karena itu, tujuan penelitian adalah memahami interaksi perilaku sumberdaya alam-pemangku kepentingan terhadap performa kelestarian hutan rakyat.

\section{METODOLOGI}

\section{A. Waktu dan Tempat Penelitian}

Penelitian ini dilakukan di Bogor yang dilakukan mulai Februari sampai dengan Juni 2017. Penelitian ini dilakukan dengan metode penelusuran pustaka terkait pembangunan hutan rakyat sengon.

\section{B. Metode}

Jumlah produksi kayu bulat di Indonesia dari tahun 2003-2014 sebesar 143,87 juta $\mathrm{m}^{3}$ (KPK, 2015), yang didominasi jenis akasia sebesar 22,91 juta $\mathrm{m}^{3}(52,22 \%)$, kayu meranti sebesar 4,47 juta $\mathrm{m}^{3}(10,19 \%)$, kayu rimba campuran sebesar 2,62 juta $\mathrm{m}^{3}(5,97 \%)$, dan kayu sengon/albazia sebesar 2,58 juta $\mathrm{m}^{3}$ $(5,89 \%)$. Berdasarkan asal tempat kayu bulat dihasilkan, 26,53 juta $\mathrm{m}^{3}(60,48 \%)$ dihasilkan di Pulau Sumatera dan 10,53 juta $\mathrm{m}^{3}(24,01 \%)$ dihasilkan di Pulau Kalimantan, serta 4,94 juta $\mathrm{m}^{3}(11,26 \%)$ dihasilkan di Pulau Jawa. Kayu bulat merupakan bahan baku untuk kayu industri dan kayu olahan, salah satunya kayu gergajian, kayu lapis dan mebel sebagai bahan baku konstruksi dan rumah tangga. Secara nasional, produksi kayu gergajian nasional mencapai 1,939 juta $\mathrm{m}^{3}$, sementara kayu lapis mencapai 1,634 juta $\mathrm{m}^{3}$ dan kayu furnitur mencapai 119,9 ribu $\mathrm{m}^{3}$ ( BPS, 2016).

Pulau Jawa sebagai pulau dengan tingkat pertumbuhan ekonomi tertinggi memiliki potensi pasar terbesar untuk produk kayu Indonesia. BPS (2016) mencatat penghasil kayu olahan kayu gergajian terbesar adalah Pulau Jawa sebesar 1,03 juta $\mathrm{m}^{3}(53,21 \%)$, sementara 1,08 juta $\mathrm{m}^{3}$ produksi kayu olahan kayu lapis dihasilkan di Pulau Kalimantan (66\%). Produksi kayu furnitur terbesar diproduksi di Pulau Jawa sebesar 113,55 ribu $\mathrm{m}^{3}(94,69 \%)$.

Namun demikian, produksi kayu ini tidak serta merta langsung diserap masyarakat. Masyarakat menggunakan baja ringan sebagai bahan pelengkap dan bahkan pengganti kayu untuk konstruksi. Beberapa alasan mengapa masyarakat cenderung memilih baja ringan, antara lain: tidak lapuk dimakan rayap, mempercepat durasi atau waktu pengerjaan suatu bangunan, struktur rangka baja ringan yang tentunya lebih ringan daripada kayu, hemat biaya, rangka baja ringan memiliki struktur atau material yang bisa disesuaikan dengan keadaan geografis sebuah daerah, dan mampu menjaga lingkungan (http:/lamudi.co.id, 2014). Namun menurut Kowal (2013) kontruksi kayu memiliki kemampuan meredam suhu sampai dengan $30^{\circ} \mathrm{C}$ dibanding kontruksi baja yang hanya mampu meredam suhu hingga $20^{\circ} \mathrm{C}$. Sementara berdasarkan tingkat kebisingan, konstruksi kayu mampu meredam sampai 6 desibel dibanding baja yang hanya 5 desibel. Di Papua, persentase perbandingan biaya antara bangunan yang berkonstruksi baja ringan dan bangunan yang berkonstruksi kayu sebesar 110,7\% . Nilai ini akan berbeda berdasarkan lokasi (Kowal, 2013).

Keunggulan menggunakan kayu untuk konstruksi bangunan adalah kayu merupakan sumberdaya yang dapat diperbaharui, menggunakan energi yang kecil 
dalam proses pengerjaannnya dan mampu menyimpan $\mathrm{CO}_{2}$ dalam bentuk selulosa di kayu, kesan ringan dan ramah untuk semua tipe iklim, dapat didaur ulang, dapat dikonversi menjadi energi biomassa sehingga menurunkan ketergantungan pada energi fosil (Woodard \& Milner, 2016). Namun, permasalahan yang sering dihadapi dan mempengaruhi persepsi masyarakat adalah menggunakan kayu sebagai bahan baku konstruksi cenderung tidak awet. Meski hal ini bukan menjadi akar masalah karena dapat diatasi dengan perlakuan pendahuluan sebelum kayu dijual. Untuk meningkatkan keawetan kayu maka perlu mengurangi ukuran pori sehingga volume udara menjadi kecil dan meminimalkan perubahan pada volume kayu, serta menghambat pertumbuhan jamur dan bakteri (secara tidak langsung melalui perbaikan hidrofobik atau pengisian dengan zat penghambat (Ramage et al., 2017). Selain itu, untuk mencegah serangan jamur, bakteri dan serangga (secara tidak langsung), dan juga meningkatkan ketahanan api sampai batas tertentu perlu memadamkan kelompok kimia aktif seperti kelompok hidroksil. Penggunaan bahan pengawet juga dapat dilakukan untuk membunuh jamur, bakteri dan serangga secara langsung, serta menambah kelembaban lapisan, bioagen tahan api atau $U V$-resistant pada permukaan kayu.

Uraian di atas menunjukkan bahwa ketersediaan bahan baku, teknologi pengolahan kayu serta strategi pemasaran produk kayu dapat didefinisikan dengan baik. Namun, mengapa pilihan untuk membangun dan menjaga hutan masih tidak menjadi peluang mata pencaharian yang menarik. Permasalahan lingkungan, harga, dan hukum menjadi dasar keterpurukan kayu. Untuk menyelesaikan masalah tersebut, maka industri kehutanan harus memiliki strategi berupa "to do the right thing, do things the right way, and utilize the best available tools and technologies" (Hansen, \& Juslin, 2005).
Strategi to do the right thing adalah perusahaan tidak berorientasi pada keuntungan semata melainkan harus mempertimbangkan hak-hak masyarakat sekitar hutan. Hak yang dimaksud disini adalah didefinisikan dengan tepat dan sesuai kebutuhan. Sementara strategi do things the right way adalah memahami alat yang harus digunakan dan efisiensinya. Strategi utilise the best available tools and technologies adalah kemampuan untuk memproyeksikan kebutuhan pasar dan prospek pasar.

Strategi ini tidak berjalan baik terutama pada industri lokal. Hal ini mendorong munculnya industri barang pengganti seperti baja ringan. Selisih antara produksi dan konsumsi baja ringan nasional mencapai 4 juta ton di tahun 2006, sementara permintaan baja ringan mencapai 6 juta ton dan cenderung meningkat mencapai $14,4 \%$ (Tjahajana, 2008).

Penjualan dan penggunaan baja ringan bagi konstruksi rumah sebenarnya bukanlah ancaman terhadap penggunaan kayu Indonesia. Dilaporkan bahwa produksi kayu baik di hutan alam maupun hutan tanaman terus menurun sehingga tidak mampu memenuhi kebutuhan kayu domestik. Namun demikian, penggunaan baja ringan dalam waktu panjang dan skala luas akan menurunkan keinginan masyarakat untuk menggunakan kayu. Akibatnya nilai kayu akan semakin menurun karena rendahnya permintaan. Hal ini akan mendorong konversi lahan berhutan menjadi tidak berhutan. Selain itu, masalah harga kayu yang lebih mahal dibandingkan baja ringan ikut membentuk persepsi masyarakat. Permasalahan persepsi yang terbentuk ini dapat dijelaskan atas jaringan pemasaran produk kayu dan baja ringan dan dampaknya terhadap keberadaan hutan.

Berdasarkan uraian di atas, maka dapat disampaikan pertanyaan penelitian secara sederhana yaitu "bagaimana interaksi antar agen mulai dari petani di 
hutan, industri dan masyarakat dalam menggunakan produk kayu, dan apa dampak hadirnya baja ringan yang membangun persepsi masyarakat akan adanya pengganti kayu yang lebih efektif dan efisien dalam konstruksi bangunan terhadap kelestarian hutan.

\section{Kerangka Pendekatan Masalah}

Dalam menggambarkan interkoneksi antar aktor, penelitian ini menggunakan pendekatan kerangka kerja analisis kelembagaan seperti pada Gambar 1 .

Selain itu, penelitian ini menggunakan pendekatan pemodelan sistem berbasis agen. Untuk menjawab pertanyaan penelitian tersebut, maka perlu penjelasan tentang karakteristik produk kayu, stakeholder yang terlibat, aturan apa yang digunakan yang semuanya berinteraksi dalam sebuah situasi aksi dan terjadi interaksi dengan sumberdaya hutan sehingga menghasilkan outcome berupa keberadaan hutan.

Produk kayu yang dimaksud adalah kayu untuk konstruksi yang berasal dari jenis fast growing species terutama sengon dengan daur pendek yang kebanyakan tumbuh di lahan milik. Sementara aktor yang dilibatkan adalah petani pemilik hutan rakyat yang menanam dan menjaga hutan sebagai mata pencaharian, industri pengolah kayu, dan masyarakat yang menggunakan kayu untuk membuat bangunan. Selain itu, terdapat aktor dari pemasaran baja ringan yang menjual produknya dan bersaing dengan produk kayu dalam konstruksi bangunan, serta pemerintah yang membuat regulasi pemanfaatan sumberdaya.

Aturan yang dimaksud dalam analisis ini adalah sertifikasi produk hutan, kebijakan pajak lingkungan, dan mekanisme pasar dengan outcome berupa luasan lahan bertutupan hutan. Kriteria yang digunakan adalah bersifat binomial atas ada dan tidaknya suatu lahan yang sebelumnya hutan menjadi hutan dan atau berubah menjadi peruntukan lain. Adapun bentuk hubungannya disajikan dalam diagram caussal-loop (Gambar 2).

\section{Analisis Data}

Simulasi Agent-based models (ABMs) merupakan penggambaran dari hubungan interaksi dan sebab-akibat dari perilaku agen (Shiflet \& Shiflet, 2014) . Dalam bidang ekonomi, beberapa agen yang harus dipertimbangkan adalah konsumen, institusi pemerintah, lembaga pemasaran, pembuat kebijakan, dan perlu melibatkan sejumlah aturan yang dibangun oleh setiap stakeholder. Perilaku petani (produsen) akan dipengaruhi oleh interaksi antar agen di atas. Agen akan beraksi pada sejumlah titik yang memengaruhinya seperti situasi dalam dirinya sendiri, lingkungan, dan aturan pribadi yang dipegang.

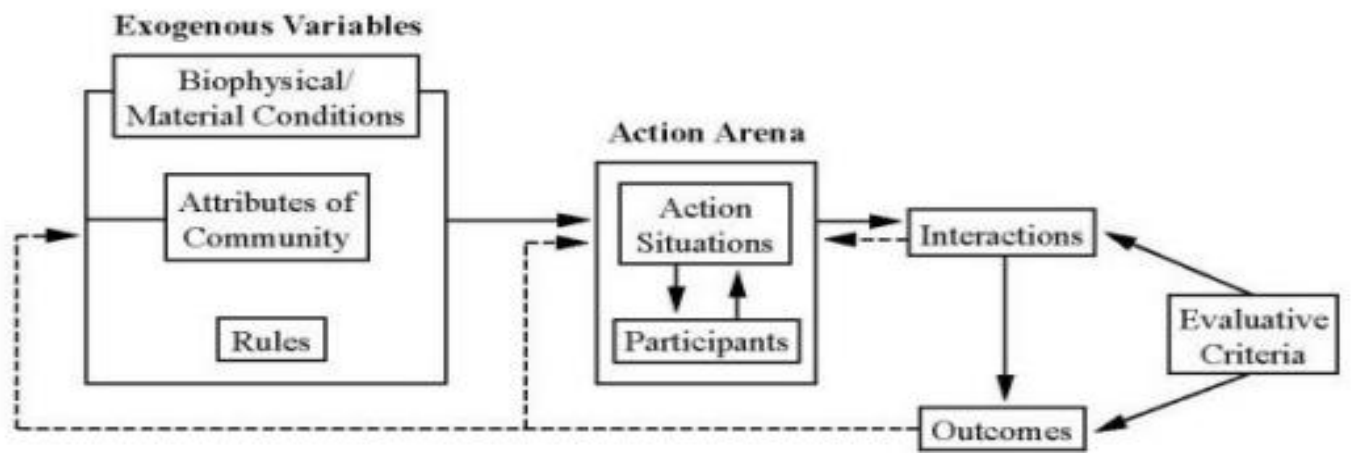

Sumber (Source): (Ostrom et al. 1994)

Gambar (Figure) 1. Kerangka kerja analisis kelembagaan (The framework of institution analysis) 


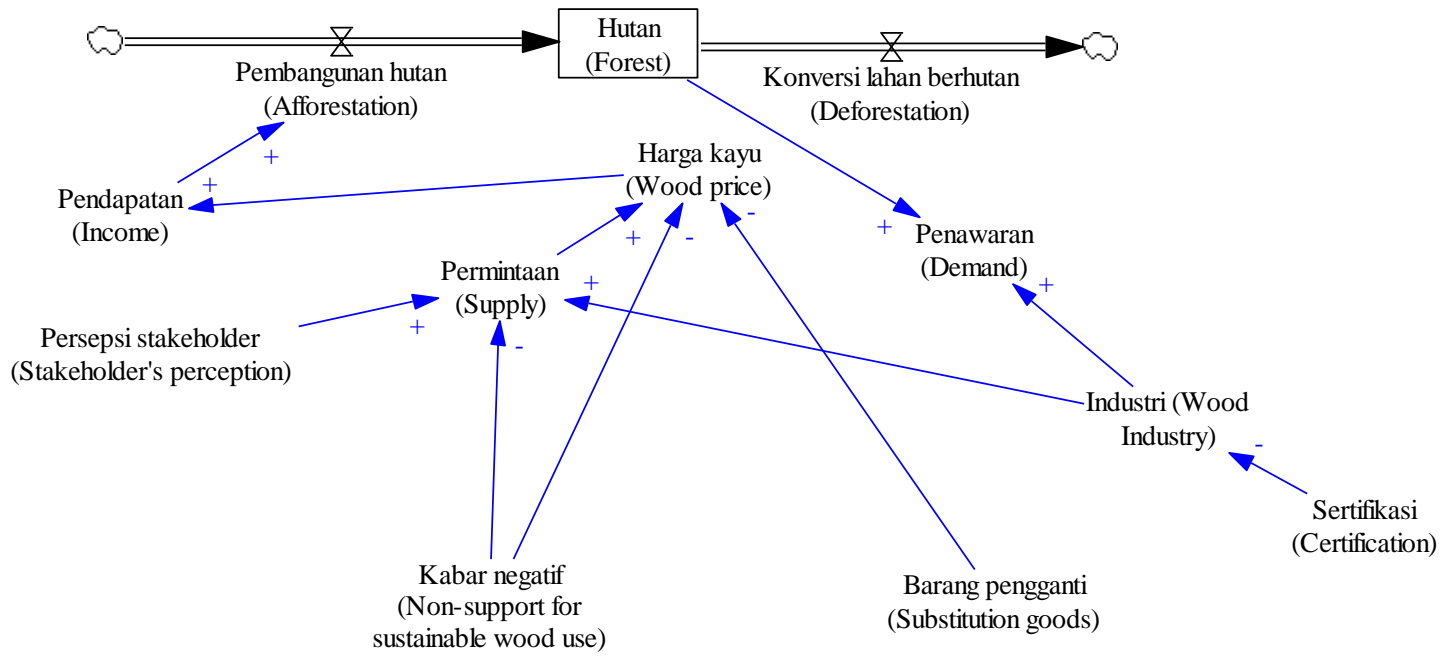

Gambar (Figure) 2. Diagram sebab akibat (Caussal-loop diagram)

Analisis data menggunakan pendekatan persepsi setiap stakeholder terhadap pasar kayu rakyat. Persepsi disini menggunakan pendapat para ahli atau hasil penelitian. Persepsi tersebut dipetakan dalam peta pengaruh (impact map) dari setiap stakeholder dan melihat interkoneksi antar stakeholder. Persepsi tersebut kemudian digambarkan dalam bentuk model agen dengan menggunakan Netlogo 6.0.1. Adapun peta pengaruh dan peran disajikan pada Gambar 3.

Pemerintah memainkan peran sebagai pengendali mekanisme pasar yang terjadi melalui insentif pembangunan hutan rakyat dengan menetapkan harga dasar kayu. Sementara petani memainkan peran sebagai penyedia bahan baku kayu, penyedia lahan untuk dikonversi. Sementara industri memainkan peran dengan membeli kayu, membeli baja ringan, menjual kayu dan membayar pajak, dan pedagang baja ringan memainkan peran dengan menjual produk baja ringan dan membayar pajak.

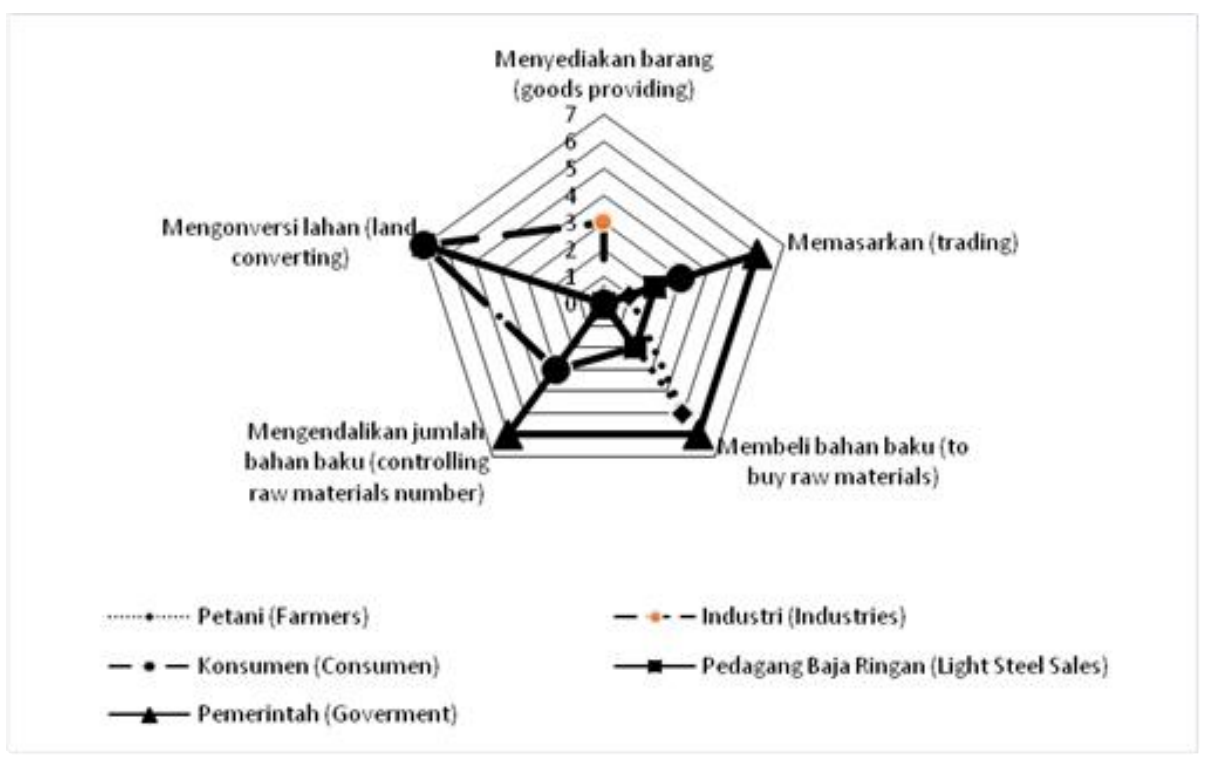

Gambar (Figure) 3. Peta pengaruh dan peran (The influence and role map) 


\section{HASIL DAN PEMBAHASAN}

\section{A. Hasil}

1. Kondisi hutan ideal dan faktanya

Tanggung jawab untuk menjaga dan meningkatkan kelestarian hutan rakyat harus dipandang sebagai sebuah sistem yang merepresentasikan peran aktor. Pengaturan peran kunci sangat penting. Dalam penelitian ini, peran kunci ada di tangan pemerintah dimana penentuan harga dasar kayu, pemantauan atas kondisi pasar dan penguatan aset petani merupakan tanggung jawab pemerintah. Selain itu, restrukturisiasi industri kehutanan penting agar kayu yang dihasilkan memiliki kualitas yang baik (Gambar 4).

Gambar 4 menunjukkan bahwa hutan rakyat dikatakan ideal jika tutupan areal berhutan dan bukan hutan tetap ada. Keberadaan ini terus dipertahankan melalui pengelolaan hutan yang menguntungkan bagi semua para pihak. Keuntungan yang diperoleh oleh petani adalah harga kayu yang lebih tinggi dibandingkan biaya pembangunan hutan rakyat .
Harga kayu merupakan instrumen interaksi antar pemangku kepentingan. Harga kayu akan menurun dan meninggalkan nilai harapan petani atas kayu bila ada barang substitusi. Dalam pemodelan ini barang substitusi berasal dari hadirnya baja ringan. Bila kondisi ini terus terjadi, maka petani akan mengonversi lahannya ke peruntukan lain dan fenomena ini disebut dengan istilah deforestasi.

Gambar 5 menunjukkan bahwa dampak harga kayu yang terus menurun (warna kuning yang semakin ditutupi dengan warna merah) dan tidak sejalan dengan biaya pembangunan hutan rakyat atau nilai lahan untuk pertanian, permukiman, dan lain-lain, mengakibatkan petani cenderung mengonversi lahan untuk peruntukan lain. Hal ini kemudian berakibat hilangnya kayu dari peredaran untuk bahan baku konstruksi bangunan rumah, dan sebaliknya permintaan baja ringan sebagai barang substitusi kayu akan meningkat.

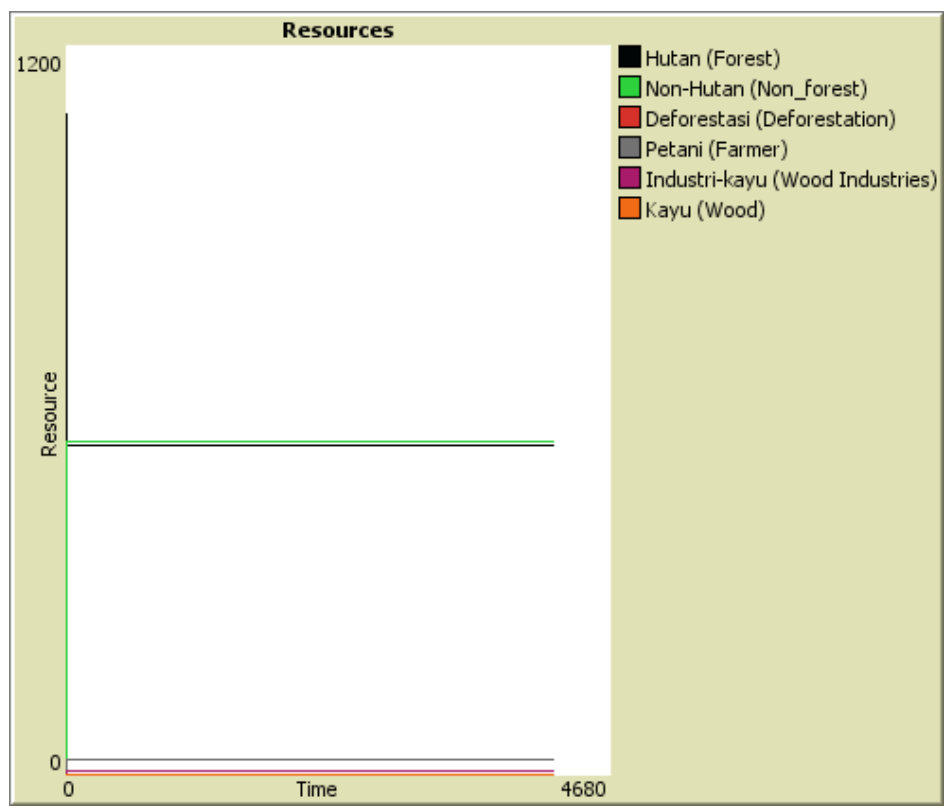

Gambar (Figure) 4. Kondisi ideal dari pengelolaan hutan rakyat yang berkelanjutan (Ideal condition of the sustainable private forest management). 


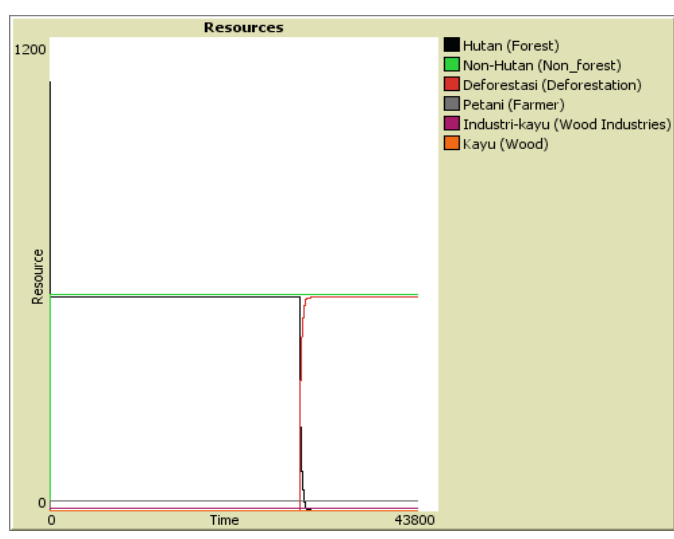

Gambar (Figure) 5. Dampak persaingan bahan baku competition)

Permintaan impor baja ringan yang meningkat pada suatu saat akan menciptakan ketergantungan terhadap baja ringan yang kemudian berakibat pada naiknya harga baja ringan. Jika barang subsititusi tidak tersedia, maka akan mengakibatkan konsumen mengalami kesulitan untuk mendapatkan rumah dengan harga terjangkau/murah. Selain itu, kerusakan lingkungan dan dampak hilangnya hutan akan terus meningkat sehingga mempersulit kondisi ekonomi dan lingkungan.

\section{Skenario pengelolaan hutan rakyat}

\section{a. Skenario penetapan harga dasar kayu}

Untuk meningkatkan daya tahan petani terhadap mekanisme pasar memang diperlukan campur tangan pemerintah. Penetapan harga dasar oleh pemerintah merupakan strategi yang sesuai. Beberapa strategi pemerintah lainnya yang telah dijalankan adalah:

1) memberikan bantuan bibit kepada masyarakat untuk membangun hutan rakyat. Strategi ini baik karena biaya untuk membeli bibit menjadi rendah dan bahkan tidak ada. Dengan demikian, harga kayu dapat ditekan sehingga meningkatkan suplus konsumen. Permasalahannya adalah bibit yang digunakan bukan bibit dengan kualitas unggul;

2) strategi inovasi teknologi pengawetan kayu di tingkat petani dan industri

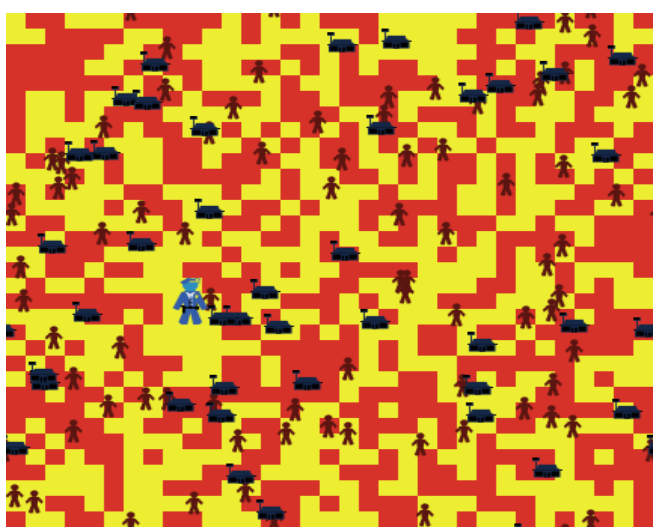

(The impact of raw material

kayu kecil. Hal ini akan berdampak positif yaitu surplus produsen yang meningkat, produk kayu mampu bersaing dengan kompetitornya, serta produktivitas petani meningkat. Namun, kelemahan dari strategi ini adalah investasi yang diberikan besar (Nurrochmat et al., 2016).

Penetapan harga dasar sebesar nilai harapan petani akan mendorong harga kayu naik sehingga produktivitas naik. Namun, penetapan harga dasar harus tidak statis melainkan harus terus mempertimbangkan komponen produksi agar harga dasar tidak di bawah nilai harapan petani.

Gambar 6 menunjukkan bahwa penetapan harga dasar kayu efektif untuk mendorong produktivitas petani (adanya titik berwarna hijau), namun jika tidak dilakukan perbaikan penetapan harga dasar maka produktivitas petani akan turun meski tidak sampai ke angka nol. Agar petani mampu mempertahankan keberadaan hutan rakyat dan tidak terpengaruh oleh mekanisme pasar yang terjadi, maka perlu pengelolaan aset seperti aset sosial, sumberdaya manusia, finansial, fisik, dan sumberdaya alam (Oktalina, Awang, Hartono, \& Suryanto, 2016).

Untuk mengendalikan penurunan produktivitas petani, maka diperlukan upaya meningkatkan posisi tawar petani 
melalui pertimbangan umur tebangan, peningkatan aksesibilitas petani terhadap lembaga keuangan, pengem-bangan sistem informasi pasokan kayu, dan kebutuhan kayu sehingga kondisi pasar dapat diakses semua pihak serta pengembangan sentra-sentra kayu.

\section{b. Skenario pembentukan kartel perdagangan kayu}

Ilham (2009) dan Nurrochmat et al. (2016) mengusulkan strategi kartel perdagangan kayu rakyat dengan komposisi petani-industri-pedagang. Skema ini akan berjalan efektif apabila profit yang diterima masing-masing agen atau komponen pemasaran tersebut tinggi, semua ikut berpartisipasi dan patuh pada aturan kartel, penerapan kuota yang ketat bagi setiap anggota, serta elastisitas harga yang rendah.

Penentuan harga kayu bersifat dinamis seiring berubahnya faktor produksi pembangunan hutan tanaman rakyat. Nilai tersebut antara lain berupa perubahan suku bunga untuk pembangunan hutan rakyat dan skema ini akan berjalan dengan baik jika kesejahteraan dan keadilan menjadi pertimbangan utama bagi semua pihak.
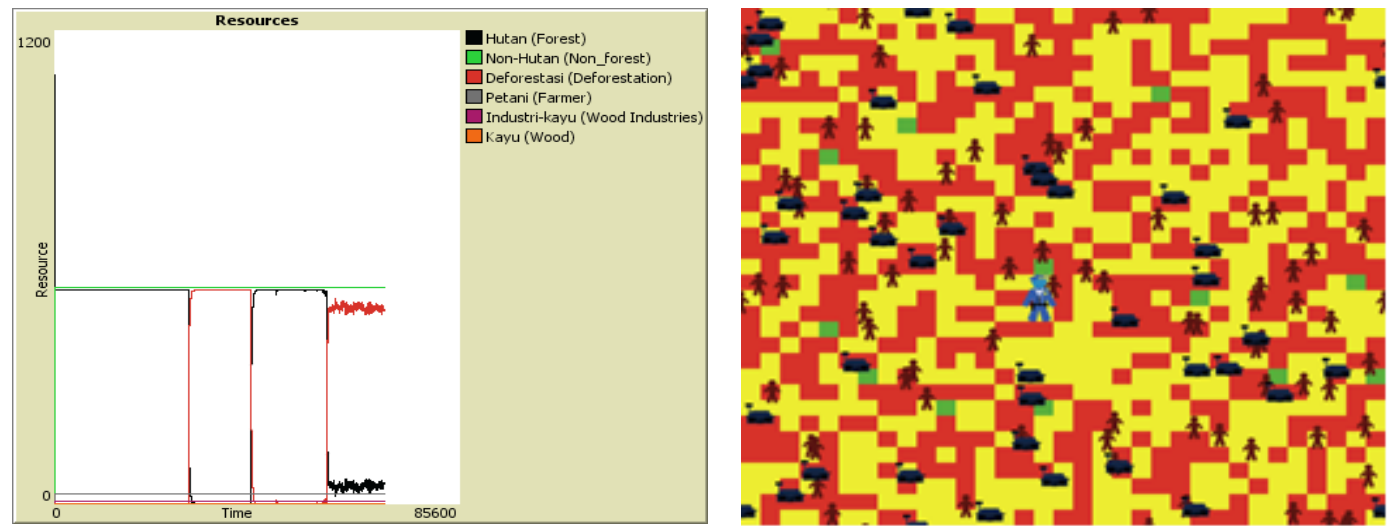

Gambar (Figure) 6. Dampak penetapan harga dasar kayu (The impact of wood base price)

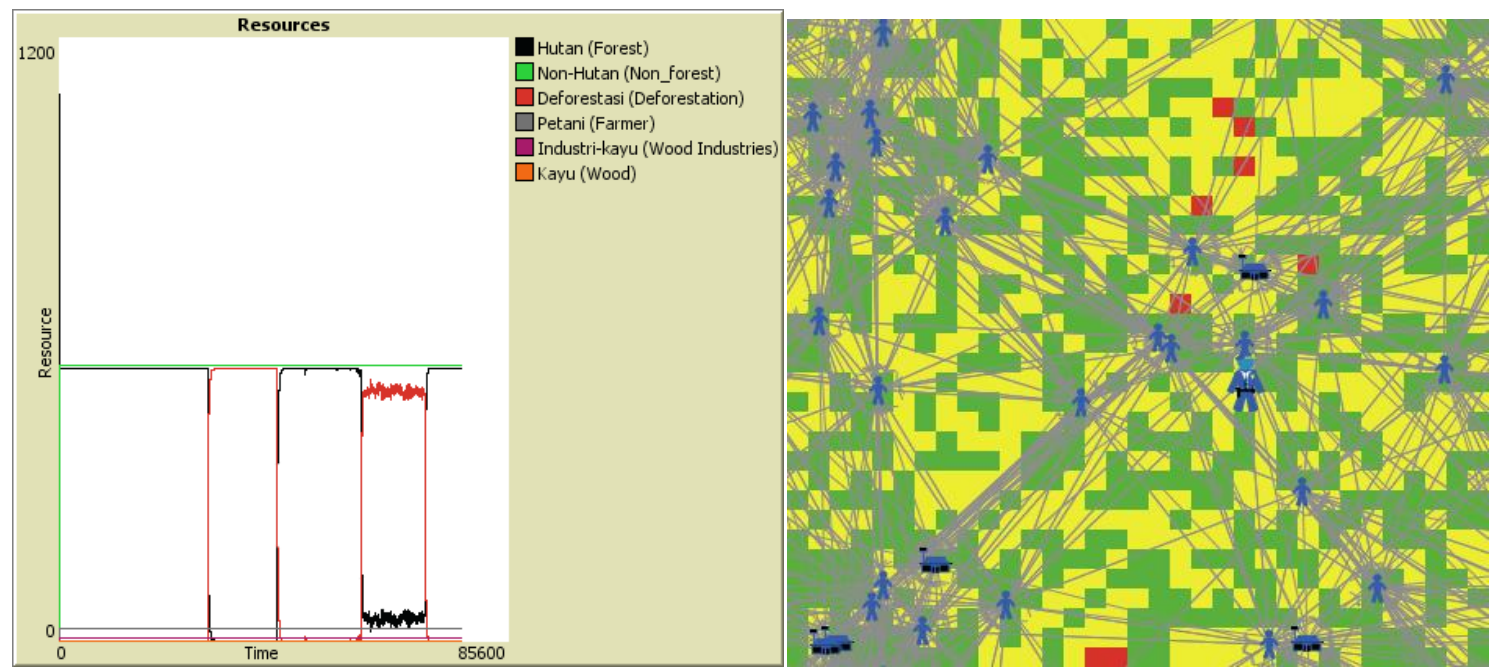

Gambar (Figure) 7. Dampak kartel perdagangan terhadap tutupan lahan (The impact of trade cartel to land cover) 
Tutupan lahan akan kembali "hijau" (titik berwarna hijau semakin banyak) jika harga kayu selalu berada di atas biaya yang dikeluarkan dalam membangun hutan. Harga kayu pun bersifat adaptif akibat dari perubahan biaya dari setiap faktor produksi. Hal ini dapat ditempuh dengan strategi total margin proporsional yang diatur dalam aturan kartel agar bagi hasil lebih adil sesuai peran dan tingkat kontribusi melalui kelembagaan kartel perdagangan (Roma, \& Perrone, 2016).

Gambar 8 menunjukkan proyeksi tutupan lahan yang akan terjadi. Bila produk kayu di hutan rakyat dibeli dan digunakan, maka petani akan terus menanam kembali lahannya dengan pohon (Gambar 8a: proporsi warna hijau dan kuning hampir sama dan tetap). Meski, harga yang ditawarkan tidak selamanya lebih besar dari biaya pembangunan hutan ditambah suku bunga investasi.
Kondisi tersebut akan berubah ketika terdapat kompetitor seperti baja ringan. Kehadiran barang substitusi seperti baja ringan dengan harga yang relatif lebih murah dan umur pemakaian yang lebih lama akan menurunkan permintaan produk kayu dari hutan rakyat (Gambar 8b: warna hijau sudah berubah menjadi merah). Kondisi ini mengakibatkan harga kayu rendah dan pendapatan petani akan menurun sehingga tidak menarik untuk menanam kembali lahannya dengan pohon.

Jika kondisi tersebut diatasi dengan menentukan harga dasar kayu dari hutan rakyat yang bersifat statis dan tidak responsif terhadap perubahan harga faktor produksi lainnya, maka kebijakan ini hanya efektif di awal saja (Gambar 8c: ada warna hijau yang mulai muncul), namun tidak menyelesaikan permasalahan dalam waktu yang lama.

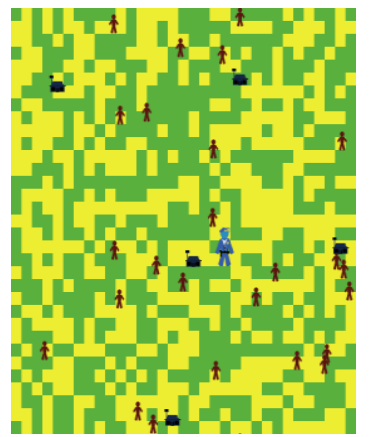

(a)

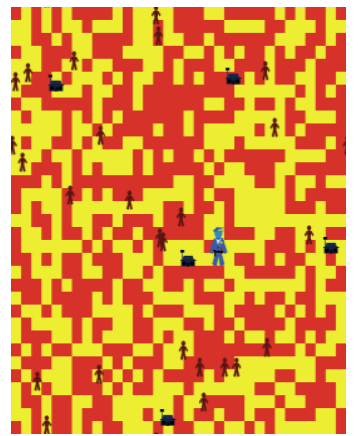

(b)

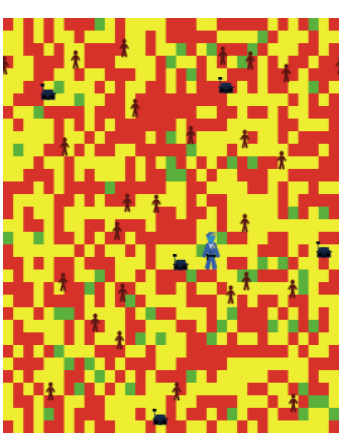

(c)

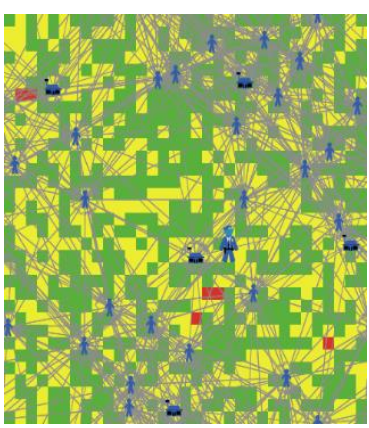

(d)

Keterangan (Remarks):

(a) Kondisi tutupan lahan sebelum adanya kompetitor produk kayu (Land cover condition before the presence of wood products competitor)

(b) Kondisi tutupan lahan setelah adanya kompetitor produk kayu (Land cover condition after the presence of wood products competitor)

(c) Kondisi tutupan lahan dengan skenario penetapan harga dasar (Land cover condition with base price scenario)

(d) Kondisi tutupan lahan dengan skenario kartel perdagangan (Land cover condition with trade cartel scenario)

Gambar (Figure) 8. Dinamika perubahan tutupan lahan akibat perubahan kebijakan perdagangan kayu (The dynamic of land cover cause of wood trade policy change). 
Untuk itu, perlu adanya asosiasi sebagai wujud nyata dari kartel perdagangan antara: petani-pedagangkonsumen (Gambar 8d: warna hijau mendominasi dengan proporsi yang sama dengan warna kuning). Beberapa aturan main (kelembagaan) perlu dibangun dan disepakati serta dikontrol komitmen pelaksanaannya. Dengan ini, petani akan memiliki akses untuk menyampaikan biaya pembangunan hutan rakyat dan proyeksi biaya pada beberapa waktu ke depan. Pedagang dibagi atas dua tipe yakni pedagang yang sifatnya membeli pohon di hutan rakyat (tengkulak) dan pedagang yang menjual produk hasil olahan. Tengkulak harus dilibatkan dalam kartel ini agar tidak saling menjatuhkan harga. Sementara pedagang produk akhir tentunya memiliki arena yang lebih luas dan tidak terbatas pada lokasi di sekitar hutan rakyat.

Konsumen juga dibagi dua tipe yakni konsumen dari sektor industri pengolahan kayu dan konsumen akhir. Konsumen di sektor industri akan menyampaikan biaya produksi untuk menghasilkan produk tertentu. Hal ini bertujuan untuk meningkatkan serapan kayu rakyat namun tidak semena-mena dalam menentukan harga bahan baku. Sementara konsumen akhir diharapkan dapat menggunakan produk kayu ini sesuai dengan kebutuhan. Pada konsumen ini yang berperan adalah pendapatan perkapita.

\section{B. Pembahasan}

Hasil penelitian ini mampu memproyeksikan kondisi pengelolaan hutan berdasarkan sejumlah penelitian yang terpisah. Pemikiran berbasis agen yang dikembangkan ini menempatkan hasil penelitian sebagai informasi dalam memprediksi kondisi hutan rakyat ke depan. Dari penelitian ini, perilaku agen ditunjukkan dengan respon positif (ya) atau negatif (tidak) atas sebuah kondisi. Persepsi ini dapat divisualisasikan dalam bentuk diagram. Hasil penelitian menunjukkan bahwa perilaku agen akan mengubah lahan (patches) dan tidak sebaliknya.

Hasil pemodelan perilaku agen di atas menunjukkan bahwa permasalahan utama dalam membangun hutan rakyat lestari adalah kepastian pasar dan harga jual kayu. Parameter harga yang digunakan dalam penelitian ini lebih singkat dibandingkan penelitian lainnya. (Sukwika, Darusman, Kusmana, \& Nurrochmat, 2018) menunjukkan bahwa dalam menyusun kebijakan pengelolaan hutan rakyat harus mempertimbangkan pendapatan petani, pedagang, upaya petani dalam meningkatkan kualitas kayu, tingkat kemiskinan petani, jumlah penyuluh kehutanan, dan program penyuluhan pertanian dan kehutanan. Sementara Park, Lee, \& Song (2017) menjelaskan bahwa keberhasilan pembangunan hutan rakyat ditentukan oleh dua kondisi yakni: investasi dan teknologi pembangunan hutan rakyat itu sendiri.

Penelitian berbasis agen seperti ini lebih mengarah pada pendapat individu dibandingkan perannya dalam kelompok. Hal ini berbeda dengan penelitian yang dilakukan oleh Sukwika et al. (2018) dan Park et al. (2017) yang lebih mengarah pada pertimbangan pembangunan hutan rakyat di komunitas tertentu. Hal yang membedakan dari kedua penelitian tersebut adalah adanya aturan kelompok yang mengatur pembuatan keputusan oleh setiap anggotanya pada penelitian berbasis komunitas .

Pengelolaan hutan rakyat lestari dapat diwujudkan dengan memperhatikan interaksi antar pelaku yang ditunjukkan oleh harga kayu di atas yang diharapkan oleh petani, namun juga tidak terlalu mahal bagi konsumen. Selain itu, harga kayu harus menjamin kualitas kayu yang lebih baik dari barang substitusi yang hal ini tentunya merupakan hal yang sulit. Untuk mengatasi hal ini, maka diperlukan 
strategi yang tepat yaitu melalui pembatasan peredaran barang substitusi di daerah tertentu saja.

Agar harga kayu dapat lebih baik, juga diperlukan beberapa strategi lain yakni: (1) usaha pengelolaan hasil hutan atau industri kehutanan skala kecil diletakkan di pedesaan dan melekat dengan pembangunan hutan rakyat (Suharjito \& Purwawangsa, 2014); (2) pembentukan koperasi hutan rakyat untuk meningkatkan ketahanan ekonomi rakyat (Subekti et al, 2016; Sukwika et al., 2018); (3) menerapkan strategi "responsible marketing atau environmental marketing dalam pemasaran produk kayu (Hansen \& Juslin, 2005); (4) memahami stakeholder utama dalam penyusunan kebijakan hutan rakyat yakni pekerja, masyarakat lokal, masyarakat secara umum, konsumen, dan aktor yang terlibat dalam rantai nilai sumberdaya tersebut (Lehmann, Russi, Bala, Finkbeiner, \& Fullana-i-Palmer, 2011); (5) membangun kerjasama antar kompetitor dalam pemasaran produk (Roma, \& Perrone, 2016); dan (6) meningkatkan pendapatan masyarakat secara luas (Kayo et al., 2015) melalui sistem kontrak yang disepakati bersama (Kamal, Grodzinska-Jurczak, \& Brown, 2015).

\section{KESIMPULAN DAN SARAN}

\section{A. Kesimpulan}

Penggunaan pendekatan pemodelan berbasis aktor sangat baik untuk meramalkan dampak pembuatan keputusan dari setiap petani sebagai pemilik hutan rakyat. Prinsip dasarnya adalah hanya ada dua pilihan yakni "ya" atau "tidak". Dengan pemodelan ini, maka dampak pembuatan keputusan dapat divisualisasikan. Pilihan tersebut akan diambil bila skenario yang diusung sesuai dengan pilihan individu. Dalam penelitian ini mengusung skenario kartel perdagangan merupakan solusi dalam menjaga kelestarian pembangunan hutan rakyat.

\section{B. Saran}

Penelitian ini masih perlu dikembangkan dengan menambahkan variabel biaya dan ambang batas (carrying capacity) setiap petani dalam menginvestasikan modalnya dalam membangun hutan rakyat. Selain itu, perlu menambahkan variabel tingkat dan pola konsumsi kayu rakyat.

\section{UCAPAN TERIMA KASIH}

Terima kasih kami sampaikan Prof. Herry Purnomo, Dr. Budi Kuncahyo, Dian Setiawan S.Hut yang telah bersedia berdiskusi selama proses penyusunan model dan artikel ini.

\section{DAFTAR PUSTAKA}

Badan Pusat Statistik [BPS]. (2016). Statistik Produksi Kehutanan. Jakarta: Badan Pusat Statistik.

Hansen, E., \& Juslin, H. (2005). Marketing of forest products in a changing world. New Zealand Journal of Forestry Science, 35(2), 190-204.

Hefni, A., Lahjie, A.M., Sardjono, M.A., Ruchaemi, A., \& Agang, M.W. (2012). Optimalisasi pendapatan hutan tanaman jenis meranti merah, sengon, mahoni, pulai dan bayur dalam kombinasi pengelolaan di Kalimantan Timur. Jurnal Hutan Tropis, 13(2), 159-172.

http:/lamudi.co.id. (2014). Pengertianbaja-ringan-dan-beberapa-alasanmemilih-baja-ringan. https://doi.org/ 1037//0033-2909.I26.1.78

Ilham, N. (2009). Kebijakan pengendalian harga daging sapi nasional. Analisis Kebijakan Pertanian, 7(3), 211-221.

Kamal, S., Grodzinska-Jurczak, M., \& Brown, G. (2015). Conservation on private land: a review of global strategies with a proposed 
classification system. Journal of Environmental Planning and Management, 58. https://doi.org/ $10.1080 / 09640568.2013 .875463$

Karvonen, J., Halder, P., Kangas, J., \& Leskinen, P. (2017). Indicators and tools for assessing sustainability impacts of the forest bioeconomy. Forest Ecosystems, 4.

Kayo, C., \& Noda, R. (2018). Climate change mitigation potential of wood use in civil engineering in Japan based on life-cycle assessment. Sustainability (Switzerland), 10(2). https://doi.org/10.3390/su10020561

Kayo, C., Oka, H., \& Hashimoto, S. (2015). Socioeconomic development and wood consumption. https://doi.org/10.1007/s10310-0150481-6

Kayo, C., Tsunetsugu, Y., \& Tonosaki, M. (2015). Climate change mitigation effect of harvested wood products in regions of Japan. Carbon Balance and Management, 10(1). https://doi.org/10.1186/s13021-0150036-3

Kowal, F. (2013). Evaluasi Bangunan Konstruksi Baja Ringan dan Konstruksi Kayu Ditinjau Dari Aspek Ekonomi. Universitas Gadjah Mada.

KPK. (2015). Mencegah Kerugian Negara Di Sektor Kehutanan. Direktorat Penelitian dan Pengembangan Kedeputian Pencegahan Komisi Pemberantasa Korupsi Republik Indonesia. Jakarta. Retrieved from https://acch.kpk.go.id/images/tema/li tbang/pengkajian/pdf/LaporanPNBP-Kehutanan-KPK-reportweb.pdf

Lehmann, A., Russi, D., Bala, A., Finkbeiner, M., \& Fullana-i-Palmer, P. (2011). Integration of social aspects in decision support, based on life cycle thinking. Sustainability,
3(4), 562-577. https://doi.org/ 10.3390/su3040562

Nurrochmat, D.R., Darusman, D., \& Ekayani, M. (2016). Kebijakan Pembangunan Kehutanan dan Lingkungan. Bogor: IPB Press.

Oktalina, S.N., Awang, S.A., Hartono, S., $\&$ Suryanto, P. (2016). Pemetaan aset penghidupan petani dalam mengelola hutan rakyat di Kabupaten Gunungkidul. J. Manusia Dan Lingkungan, 23(1), 58-65.

Osburg, V.S., Appelhanz, S., Toporowski, W., \& Schumann, M. (2016). An empirical investigation of wood product information valued by young consumers. Journal of Cleaner Production, 110, 170-179. https://doi.org/10.1016/j.jclepro.201 5.01 .068

Ostrom, E., Gardner, R., Walker, J., Agrawal, A., Blomquist, W., Schlager, E., \& Thang, S.Y. (1994). Rules, Games, and Common-Pool Resources. The University of Michigan Press.

Park, H., Lee, J.Y., \& Song, M. (2017). Scientifiec activities responsible for successful forest greening in Korea. Forest Science and Technology, 13, 1-8. $\quad$ https://doi.org/10.1080/ 21580103.2016.1278048

Ramage, M.H., Burridge, H., BusseWicher, M., Fereday, G., Reynolds, T., Shah, D. U., ... Scherman, O. (2017). The wood from the trees: The use of timber in construction. Renewable and Sustainable Energy Reviews, 68(September 2016), 333359 . https://doi.org/10.1016/j.rser. 2016.09.107

Roma, P., \& Perrone, G. (2016). Cooperation among competitors: A comparison of cost-sharing mechanisms. Int. J. Production Economics, 180, 172-182.

Shiflet, A.B., \& Shiflet, G.W. (2014). An 
Introduction to Agent - Based Modeling for Undergraduates. Procedia - Procedia Computer Science, 29(Building 2010), 13921402. https://doi.org/10.1016/j. procs.2014.05.126

Subekti, I., Martono, E., \& Hamid, E.S. (2016). Manajemen koperasi dalam rangka pengelolaan hutan rakyat dan pengaruhnya terhadap ketahanan ekonomi masyarakat (Studi Pada Koperasi Wana Lestari Menoreh di Kabupaten Kulon Progo , DIY ). Jurnal Ketahanan Nasional, 22(2), 158-179.

Suharjito, D., \& Purwawangsa, H. (2014). Percepatan devolusi pengelolaan hutan. Risalah Kebijakan Pertanian Dan Lingkungan, 1, 12-17.

Sukwika, T., Darusman, D., Kusmana, C., \& Nurrochmat, D.R. (2018). Skenario Kebijakan Pengelolaan Hutan Rakyat Berkelanjutan di Kabupaten Bogor. Jurnal Pengelolaan Sumberdaya Alam dan Lingkungan (Journal of Natural Resources and Environmental Management), 8(2), 207-215. https://doi.org/10.29244/ jpsl.8.2. 207-215

Taylor, J., \& Langenberg, V. K. (2003). Review of the Environmental Impact of Wood Compared with Alternative Products Used in the Production of Furniture, 1-16.

Tian, M., Li, L., Wan, L., Liu, J., \& de Jong, W. (2017). Forest product trade, wood consumption, and forest conservation - the case of 61 countries. Journal of Sustainable Forestry, 36(7), 717-728. https://doi.org/10.1080/ 10549811. 2017.1356736

Tjahajana, A. (2008). Strategi Memperkuat Industri Baja Nasional. Media Industri, (02).

Woodard, A.C., \& Milner, H.R. (2016). Sustainability of timber and wood in construction. Sustainability of Construction Materials (Second Edi). Elsevier Ltd. https://doi.org/10.1016/B978-0-08100370-1.00007-X 